\title{
Na cozinHa da PESQUisa: Relato de experiênCIA Na disciplina "Métodos e Técnicas em Antropologia Social"
}

\author{
Fabiene Gama e Soraya Fleischer ${ }^{1}$ \\ UnB, Brasília, Brasil
}

\begin{abstract}
Este artigo trata da experiência de realização de uma disciplina de graduação sobre métodos e técnicas de pesquisa em antropologia social. A disciplina, comum a diversos cursos de Ciências Sociais, foi desenvolvida de forma bastante prática, baseada em atividades de leitura e escrita, oficinas (desenho, fotografia, vídeo) $e$ também cinco saidas de campo realizadas conjuntamente, que produziram materiais a serem discutidos em sala de aula. Nela, as etapas mais comuns de uma pesquisa, assim como as diferentes técnicas para realizá-las, foram apresentadas $e$ desenvolvidas a partir de experiências muito concretas, com o objetivo de incentivar que a realidade experimentada pelas estudantes respirasse com ares mais criticos e reflexivos. O artigo, dessa forma, busca contribuir para a prática docente em antropologia.
\end{abstract}

Palavras-chave: antropologia, métodos de pesquisa, criatividade, aprendizado horizontal

\section{INTRODUÇÃO}

Em geral, artigos científicos antropológicos apresentam e discutem resultados de alguma experimentação empírica. Contudo, poucos são aqueles que apresentam e discutem resultados de uma experimentação de natureza didática (Sanabria 2005: 15). Grande parte de nosso tempo enquanto acadêmicas é passado em sala de aula, mas pouco somos estimuladas a refletir sobre o conhecimento que produzimos em companhia das estudantes ${ }^{2}$. Por enquanto, há poucos espaços específicos nos periódicos da área para esse tipo de relato, embora alguns textos tenham sido

$1 \quad$ Contato: fabienegama@gmail.com e fleischer.soraya@gmail.com.

2 Optamos pelo plural feminino tanto porque éramos duas professoras quanto porque a turma contava com a maioria de estudantes do sexo feminino. Aproveitamos para agradecer a essa turma pela disponibilidade em aceitar nossa proposta e permitir que utilizássemos aqui trechos de seus depoimentos e materiais produzidos. Todas as fotos do artigo, com exceção das imagens de Henrique Rocha, são de autoria de Fabiene Gama. 
publicados (Grossi et al 2006; Tavares et al 2010; Fleischer 2012; Fleischer et al 2014; Gama e Kuschnir 2014; Schweig 2015; Sanabria 2005) e, de modo mais expressivo, eventos tenham sido organizados nesse sentido (Sanabria 2005: 12).

Sanabria lembra que um dos principais interesses "no ensino atualizaria a capacidade de auto-reflexão atribuída com freqüência à antropologia" (2005: 13) e Schweig (2015: 18), baseando-se em Ingold (2014), aponta para o fato de que a educação é uma dimensão do conhecimento antropológico. E que a Antropologia é uma "correspondência educacional com a vida real", à medida em que pressupõe o desenvolvimento de "habilidades de percepção e capacidades de julgamento" sobre o mundo. Desse modo, o presente artigo pretende contribuir para a discussão sobre a prática docente na Antropologia ao refletir sobre a elaboração e a condução de uma disciplina obrigatória oferecida no Departamento de Antropologia da Universidade de Brasília (DAN). O curso, "Métodos e Técnicas em Antropologia Social (MTAS)", foi por nós assumido no primeiro semestre de 2015 e tinha $90 \mathrm{~h}$, distribuídas em 15 semanas, com três encontros de $2 \mathrm{~h}$ por semana. Naquela ocasião, contou com 36 estudantes.

Em nossa compreensão, MTAS pretende “apresentar dimensões das práticas de pesquisa em antropologia social de modo a, entre outras coisas, capacitar para a preparação de pesquisas etnográficas e também da monografia de conclusão de curso" (programa de curso, 2015) ${ }^{3}$. Quer dizer, não apenas estimular as estudantes a considerar a monografia como uma oportunidade factível e criativa (já que muitas estudantes optam por não a realizar para se formarem apenas como "Bacharel em Ciências Sociais"), como também a incentivá-las como pesquisadoras para os desafios que enfrentarão no mercado de trabalho. Acreditamos que vale refletir sobre esta disciplina porque muitos cursos de Ciências Sociais contam com algo bastante semelhante em seu currículo. E porque a reflexão sobre o ensino dos nossos métodos, tão fundamentais para nossas atuações profissionais, é primordial para a produção de conhecimentos antropológicos. Assim, esperamos que aqui possam ser encontrados subsídios para consolidar a importância dessa disciplina na formação na área e avançar na construção de um leque cada vez mais criativo para sua realização.

Seguimos um consenso atual de que não há um manual para se fazer boa pesquisa antropológica. Embora conte com algumas publicações nesse sentido, de clássicos (Mauss 1993[1947]) aos mais recentes (Gomes 2015, para um exemplo nacional), a pós-modernidade na Antropologia tem questionado profundamente qualquer orientação monolítica da pesquisa empírica, cabendo apenas reflexões e decisões customizadas diante de cada empreendimento realizado. Como Wright-Mills (1980[1959]) sugeriu, não temos qualquer fetichismo pelo método e a disciplina não pretendeu ditar regras rígidas ou generalizáveis para as pesquisas imaginadas pelas estudantes matriculadas. Contudo, fizemos uma opção por desenhar a disciplina para que fosse muito prática e concreta. Tanto planejamos apresentar as etapas mais comuns de uma pesquisa (definição do tema, pesquisa bibliográfica, pesquisa empírica, registro dos dados e construção de uma narrativa textual/fotográfica/audiovisual), quanto as diversas técnicas para fazê-la acontecer (mapeamento geográfico e territorial; aproximação, apresentação da pesquisa e convite para participar; diálogos e monólogos; conversas e entrevistas; perguntas espontâneas ou dirigidas; gravação de áudio/vídeo e registros escritos e fotográficos; revisitação e continuação das conversas; autoria e representação; devolução de resultados; despedidas etc.). O intuito

3 Para o programa da disciplina, ver http://dan.unb.br/images/pdf/graduacao/programas-disciplinas/2015/1/ Programa_MTAS_1_2015.pdf 
não foi vulgarizar a empreitada etnográfica, mas incentivar que a realidade experimentada respirasse com ares mais críticos e reflexivos.

Como mostraremos, fizemos uma aposta por intensificar o mergulho nas técnicas e, sobretudo, por compartilhar os resultados desse mergulho. Assim, se é improdutivo apresentar um manual de pesquisa, sugerimos ser possível apresentar um repertório de experiências, dilemas e soluções. A expectativa era munir as estudantes de uma plêiade de estratégias para que, em suas pesquisas futuras, estivessem com a imaginação aguçada o suficiente para lidar com os problemas que se apresentassem e, mais importante, para inventar saídas criativas e ajustadas diante de cada caso. Nosso objetivo foi formar estudantes em técnicas de pesquisa que partissem dos usos dos clássicos gravadores e cadernos de notas, mas que os ultrapassassem ao serem atualizados e contrastados com outras formas de perceber, documentar e experimentar o mundo. A seguir, o artigo fará uma apresentação geral da disciplina. Depois, descreverá as cinco idas a campo ${ }^{4}$ e discutirá os principais resultados dessas atividades. Por fim, apontará alguns benefícios desse formato didático.

\section{MTAS EM LINHAS GERAIS}

No DAN, estudantes geralmente cursam MTAS no meio da graduação. Precisam já ter cursado outras disciplinas obrigatórias ("Introdução à Antropologia”, "Teoria Antropológica I e II"). Quem simplesmente segue o fluxo de modo contínuo e sem reprovações, chega à disciplina no quinto semestre. Mas muitas estudantes adiam propositalmente MTAS. Circula entre elas a informação de que seria necessário já ter estabelecido o tema da monografia antes de se matricular na disciplina. Algumas professoras optam por desenhar MTAS como uma antessala da pesquisa monográfica para, ao final, a estudante ter um rascunho do projeto a ser apresentado como "cartão de visita" a uma possível orientadora. Assim, muitas estudantes ficavam à espera, semestre após semestre, "de um tema para chamar de seu" (como uma estudante definiu), algo suficientemente original a ponto de lhe render a chance de ser aceita pela futura orientadora e também "se tornar um sobrenome famoso" (como outra estudante confidenciou). Notamos que poucas sabiam da possibilidade de se engajar em pesquisas já em curso, tornando-se membro de uma equipe. Ainda assim, essa alternativa era entendida como menos nobre porque o tema não fora "inventado" pela estudante.

Nós entendemos que o projeto de pesquisa será melhor construído um pouco mais à frente, junto à orientadora, e vemos MTAS como um exercício de primeiro contato com os desafios práticos da pesquisa. A ideia foi transformar MTAS em um espaço mais confortável, leve, criativo e produtivo. Assim, tentamos acolher todo mundo. Não havia exigência de que o tema já tivesse sido recortado, que fosse "descoberto" ao longo do semestre ou mesmo que a experiência se revertesse "no tema" de pesquisa monográfica. As experiências ali desenvolvidas seriam combustível para reflexão durante a disciplina. A ideia era ficar à vontade para aproveitar tudo o que pudesse surgir - positivo ou não - e construir a confiança necessária para a sensibilidade antropológica se desenvolver.

4 Em um formato pouco usual, nesta disciplina fomos a campo como turma. "Sair", assim, teve múltiplos significados: deixar a sala de aula, entrar em outro ambiente e na pesquisa. 
Além disso, no momento de MTAS, a maioria das estudantes só teve contato com disciplinas teóricas, em que leram sobre a história da Antropologia e a intensa autorrevisão feita pela área. Chegam muito afiadas, com críticas disparadas facilmente para todo lado, mas também chegam desconstruídas, desencantadas, perdidas, cheias de cuidados para não deslizarem e serem acusadas de etnocêntricas, imperialistas e/ou neocolonialistas. A maioria nunca fez pesquisa, nunca entrevistou uma pessoa, nunca abordou alguém para uma conversa. Ou seja, vêm com alguma bagagem conceitual, mas não sabem como produzir antropologia. Ao propormos algo mais prático, sentimos no início certo desconforto por parte da turma. Como se aquilo que não fosse teórico não pudesse ser legítimo; como se aquilo que não fosse produzido alhures (e, de preferência, além-mar) não pudesse ser suficiente; como se aquilo que fosse produzido por uma colega da carteira ao lado não pudesse ser conhecimento; como se aquilo que fosse produzido pelo corpo (que anda, olha, é olhado, sente etc.) e não pela linguagem verbal e escrita fosse menor. Fomos percebendo, à medida que a disciplina avançava, que partir para a prática, discutindo de modo muito singelo técnicas de pesquisa, poderia ser uma ferramenta potente para desconstruir certezas. Ao menos permitir que algumas balizas pudessem ser testadas e construídas para uso futuro.

A disciplina contou com seis diferentes tipos de aulas: 1) leitura prévia e discussão em sala de aula de textos de autoras externas; 2) leitura prévia e discussão em sala de aula de monografias de egressas do DAN; 3) participação nos "Seminários do DAN"; 4) oficinas de desenho, fotografia e vídeo; 5) saídas de campo; 6) discussões sobre as saídas. Cada tipo de aula exigia certo tipo de tarefa. Diante dos textos, monografias e seminários, esperávamos que participassem individualmente, atentas à discussão, tomando notas e colocando suas impressões sobre o que fora lido e ouvido. Aproveitamos para convidar as autoras das monografias para que contassem como haviam realizado a pesquisa e a escrita do texto. Como se espera uma monografia ao final da graduação, era preciso que as estudantes tivessem referências sobre como produzir esse artefato. No caso dos "Seminários do DAN", que aconteciam mensalmente no departamento, teriam contato com autoras conhecidas, com ampla diversidade temática e que tinham partido da pesquisa empírica e artesanal para chegar às suas conclusões mais ousadas.

Para as saídas de campo, que aconteciam a cada duas ou três semanas, elegemos uma área comercial próxima ao campus Darcy Ribeiro, o "Setor Comercial Local Norte 408/409". O Plano Piloto de Brasília é organizado em espaços residenciais e comerciais. No primeiro tipo de espaço, há pouca circulação de pessoas, sobretudo por conta da cultura automobilística que predomina na cidade. No segundo tipo, há uma intensificação de circulação e interação social, atmosfera propícia para a observação e interpelação antropológicas. Uma "quadra comercial", como dizemos, consiste em dez blocos de três andares com dezenas de lojas (salões de beleza, farmácias, botequins, mercearias, butiques, petshops, etc.) e pequenas quitinetes residenciais. Há espaços com bancos e pequenos jardins, canteiros e murais, centro de saúde, bancas de jornal, supermercado, ONGs, quiosques de chaveiros e sapateiros. Queríamos um espaço que fosse fora dos limites do campus, para que deixássemos a familiaridade da vida universitária e encontrássemos um mínimo de estranhamento e, ao mesmo tempo, que não fosse distante demais e inviabilizasse a grade horária das estudantes, já que teriam aulas antes e/ou depois de MTAS.

Essa quadra comercial era próxima o bastante para que, a partir do campus, se chegasse a pé, de bicicleta ou de carro em poucos minutos. E distante o suficiente para que a turma pudesse perceber que nem tudo que era familiar era conhecido (Velho 1981), como lembraram alguns estudantes: "Eu fiquei atordoado com o fato de as saídas de campo serem na 408. 'Que tema 
vou escolher ali?’, pensei”, contou Fernando Launé. "Eu frequentava há 15 anos essa quadra. Achava que a conhecia. Mas agora vejo que não", percebeu Matheus Sousa. Por fim, queríamos que as saídas acontecessem no período da aula para que se tornassem uma rotina, para que pudéssemos ali mesmo partilhar a experiência, vertendo os resultados para a consecução da aula, e para evitar onerar as estudantes ao terem que acionar outro turno para realizar a minipesquisa. $\mathrm{E}$ como as aulas aconteciam em diferentes espaços da universidade e de seus arredores, utilizamos o Moodle (e também e-mail, WhattsApp etc.) para manter uma comunicação fina e evitar desencontros.

A disciplina foi desenhada tendo a experimentação empírica como espinha dorsal. Isso quer dizer que o conteúdo que embalaria as discussões das aulas partiria, sobretudo, daquilo que fosse observado, registrado, fotografado, sentido e compreendido pelas estudantes a partir das saídas de campo. Como a aluna Daniela Torrentera resumiu, "As estudantes faziam a aula". Para as oficinas e saídas de campo, as estudantes se dividiram em duplas (e em alguns poucos trios) com quem trabalhariam ao longo de todo o semestre. As discussões sobre as saídas começavam em dupla, mas terminavam em uma grande roda de conversa, em que todas poderiam ver seus rostos e expressões (e não os pescoços e cabelos, como acontece na disposição das carteiras escolares em fileiras). Na roda inicial, repassávamos os objetivos daquela saída, ouvíamos como haviam planejado conduzir a pesquisa naquele dia e debatíamos as dúvidas e inseguranças que por ventura surgissem. $\mathrm{Na}$ roda final, sob a sombra dos pilotis de algum bloco residencial, as estudantes comunicavam de chofre os pontos altos e baixos enfrentados. Semelhanças eram percebidas nos aprendizados, soluções e sugestões circulavam e poderiam ser testadas na próxima saída. A mudança dos corpos dentro e fora da sala de aula ajudava a mudar de perspectiva, passavam a ver o ambiente e as pessoas por outros ângulos (ver Imagem 1).

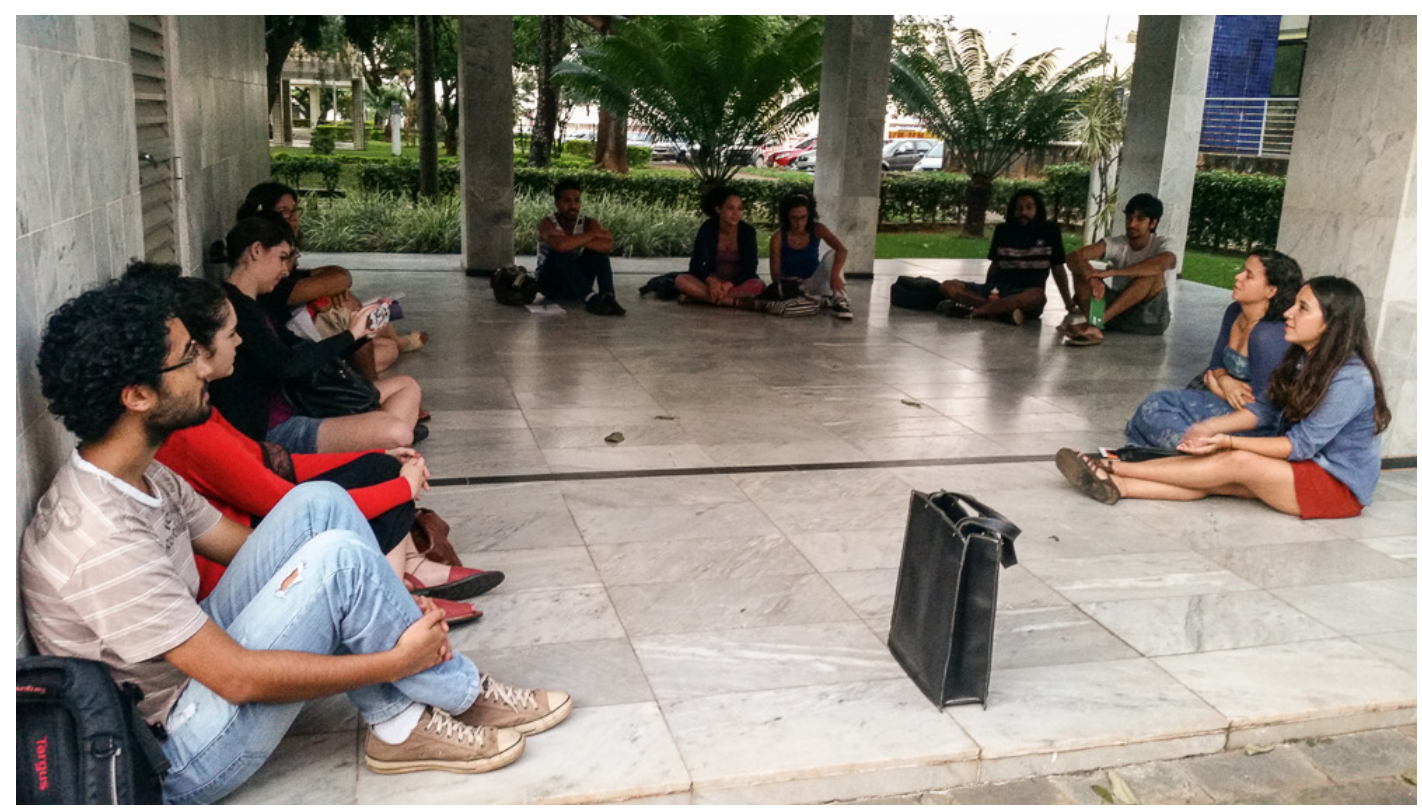

Imagem 1: Roda de conversa ao final de uma saída de campo.

Usamos novas e velhas tecnologias para registro e apresentação dos dados: caneta, papel e cadernos (para anotações, diários e desenhos), câmeras fotográficas e aparelhos de telefone celular (para gravar áudios, fazer fotos e produzir vídeos) e a Internet (para trocar textos, imagens, realizar pesquisas bibliográficas e eventualmente trabalho de campo de modo remoto). 
Além das referências teóricas, as discussões durante a disciplina também foram motivadas pelos depoimentos, diários de campo, entrevistas transcritas, desenhos, fotografias, vídeos - todos produzidos pelas estudantes. Aqui, estava em curso o que chamamos de "aprendizado horizontal", já que o conhecimento lido e aprendido tinha sido gerado pelas colegas da disciplina. Apostamos que muito já era aprendido de modo tácito e informal entre elas, mas nosso intuito foi oficializar esse tipo de conhecimento na disciplina. Esse aprendizado era também recíproco, já que aquela que lesse o texto da colega hoje, teria seu texto lido por essa mesma colega amanhã. Notamos que era muito mais fácil criticar o texto de alguém com quem dificilmente se encontrariam do que o de uma colega. Portanto, estávamos a estimular formas de questionar um texto na frente da autora, olhando em seus olhos e percebendo suas reações. Não só empatia, gentileza, paciência e respeito eram estimulados, mas a real possibilidade de que, pelos acertos e desacertos da outra, também se aprendesse novas formas de fazer (ou não) Antropologia.

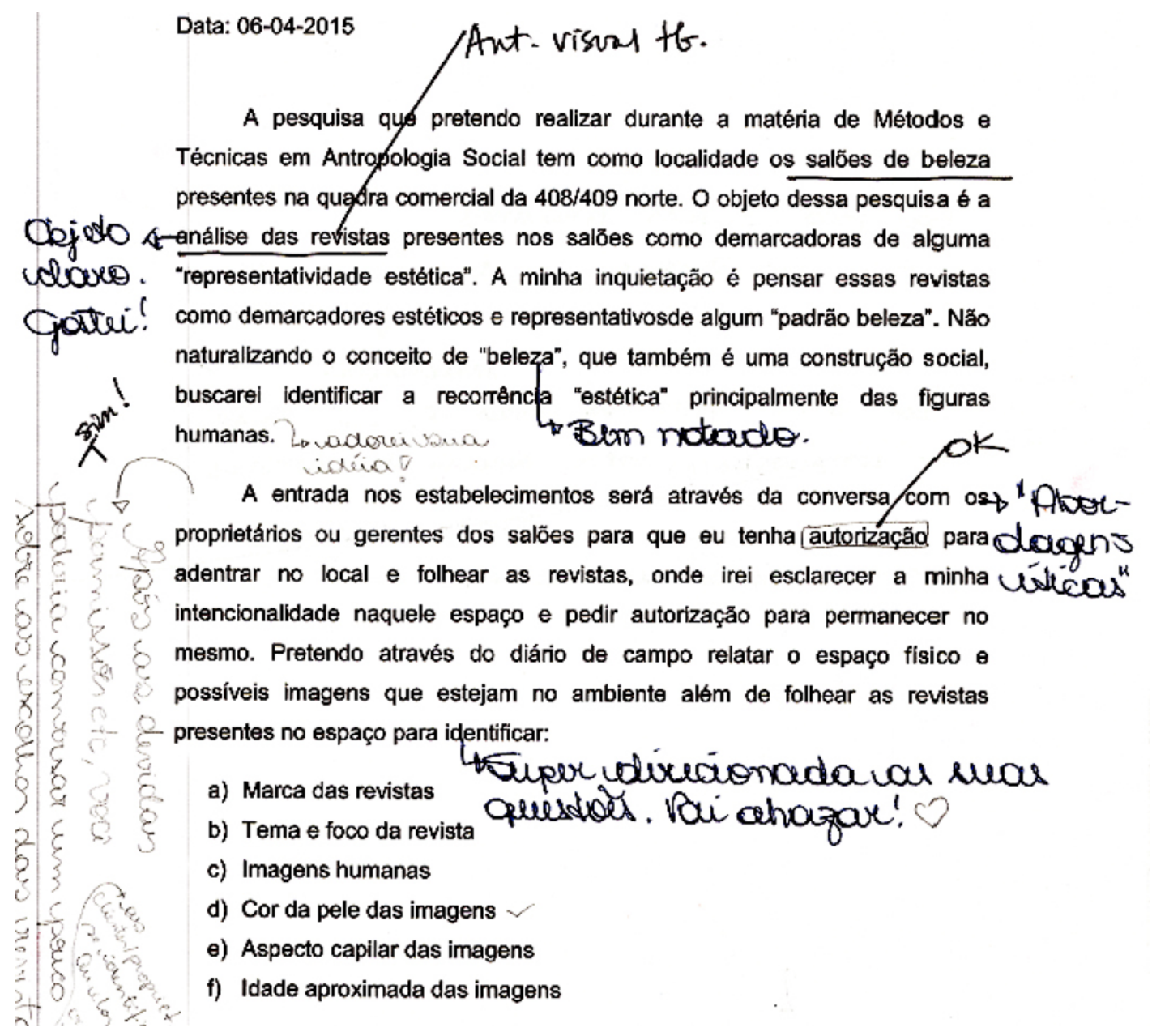

Imagem 2: Trecho do diário de campo de Ana Clara Damásio, comentado por vários colegas.

Essa estratégia se estendia também para os comentários escritos por nós e pelas colegas nos textos produzidos (ver Imagem 2). Como um diário seria lido por duas ou três pessoas, dentre elas a dupla, sugerimos que fizessem marcações com canetas de diferentes cores, permitindo que cada leitora subsequente aprendesse com os insights da anterior. Ler e reler diários de campo e entrevistas eram etapas de aproximação e compreensão dos dados. Uma mesma entrevista, por exemplo, poderia gerar muitos comentários, evidenciando, assim, a riqueza e densidade de um 
mesmo material. Recomendamos que considerassem esses comentários como um diálogo, como mais um conjunto de ideias que poderiam fazer avançar a reflexão sobre o tema de pesquisa.

No início dessa prática, notamos duas angústias. Por um lado, algumas estudantes julgavam ter que responder a todas as perguntas escritas na margem de seus textos, sendo que muitas dessas perguntas não tinham ainda respostas possíveis. Por outro lado, algumas se intimidaram em comentar os exercícios, sabendo que depois seriam lidos também pelas professoras. Estavam preocupadas de que esses comentários rebaixassem a menção da colega. Foi preciso construir paulatinamente uma atmosfera coletiva de confiança, reforçando que esperávamos que os comentários servissem para ampliar a capacidade criativa das pesquisadoras em relação aos seus temas. Por exemplo, os comentários visavam revelar lacunas de informações, sugerir perguntas a serem re/feitas em campo, oferecer insights com chance de adensar a relação com a interlocutora.

Lemos também textos de outras autoras, mais ou menos canônicas, que haviam consolidado conceitos-chave, sistematizado suas próprias experiências de pesquisa empírica, oferecendo um panorama histórico sobre as discussões metodológicas na Antropologia. Mas guardamos uma orientação importante: diminuir o número de textos externos para abrir espaço para os textos das estudantes, as saídas de campo e, mais importante, a discussão das intensas experiências das saídas. Cada encontro fora de sala demandava uma ou duas seções subsequentes de debriefing dentro de sala de aula, seja a partir dos relatos, seja pelos textos produzidos. Era comum, claro, que essas seções fossem permeadas por ideias-chave anunciadas nos textos e monografias que íamos conhecendo.

\section{As CINCO SAÍDAs de CAMPo}

Nessa seção, descreveremos as cinco saídas de campo que realizamos e alguns dos exercícios gerados. Certos exercícios foram feitos conjuntamente pela dupla, como a realização e transcrição de uma entrevista; outros foram individuais, como comentários sobre os "Seminários do DAN" ou os diários de campo. Lemos, comentamos e devolvemos cada exercício que nos foi apresentado. Sugerimos que criassem um sistema de arquivamento desse material, já indicando a importância da organização e cuidado com nossos materiais de pesquisa (Wright-Mills 1980[1959]). Eles serviriam não apenas para produzir o "trabalho final" da disciplina, mas poderiam ser reutilizados futuramente.

\section{SAÍDA 1}

Antes de realizar a primeira saída de campo, lemos textos introdutórios e organizamos uma oficina de desenho. Essa saída foi por nós chamada de "caminhada interessada", ao propormos que mapeassem a quadra comercial, sem a necessidade de interagir com seus personagens. Deveriam caminhar e olhar o território de forma despretensiosa, entender a organização do espaço, notar particularidades e estranhamentos. A ideia era chegar devagar e conseguir formular uma ambientação do lugar (Brandão 2007). Como forma de registro, sugerimos que desenhassem, ferramenta largamente utilizada (mas pouco discutida) por expoentes clássicos e contemporâneos, de Malinowski (1984[1922]) a Taussig (2011). Desejávamos que o desenho 
se transformasse em mais um aliado em campo. Recebemos a visita da antropóloga do Instituto de Artes/UnB, Luísa Günther, que nos lembrou como o desenho desafia frontalmente o que chamou de "grafocentrismo", meio de expressão tradicionalmente instalado na Antropologia (Günther 2013).

Günther tinha razão. Logo notamos que algumas estudantes resistiram a usar uma ferramenta diferente da escrita. Alegaram que "não sabiam desenhar". Tentamos desconstruir a ideia de que há um "jeito certo" de fazer um desenho ou qualquer outro produto antropológico. Lembramos da diferença entre um desenho realista e um registro gráfico, sendo este último o nosso objetivo para produzir conhecimento (Gama e Kuschnir 2014). Sugerimos que se ativessem menos à retratação realista e mais ao que Geertz (1995) sugere como tom, atmosfera do lugar, seus espaços, pessoas, arranjos. Várias estudantes se sentiram confortáveis para considerar a garatuja, o esboço, o croqui, a planta baixa e o mapa como ferramentas para apreender um campo de pesquisa (Gama e Kuschnir 2014).

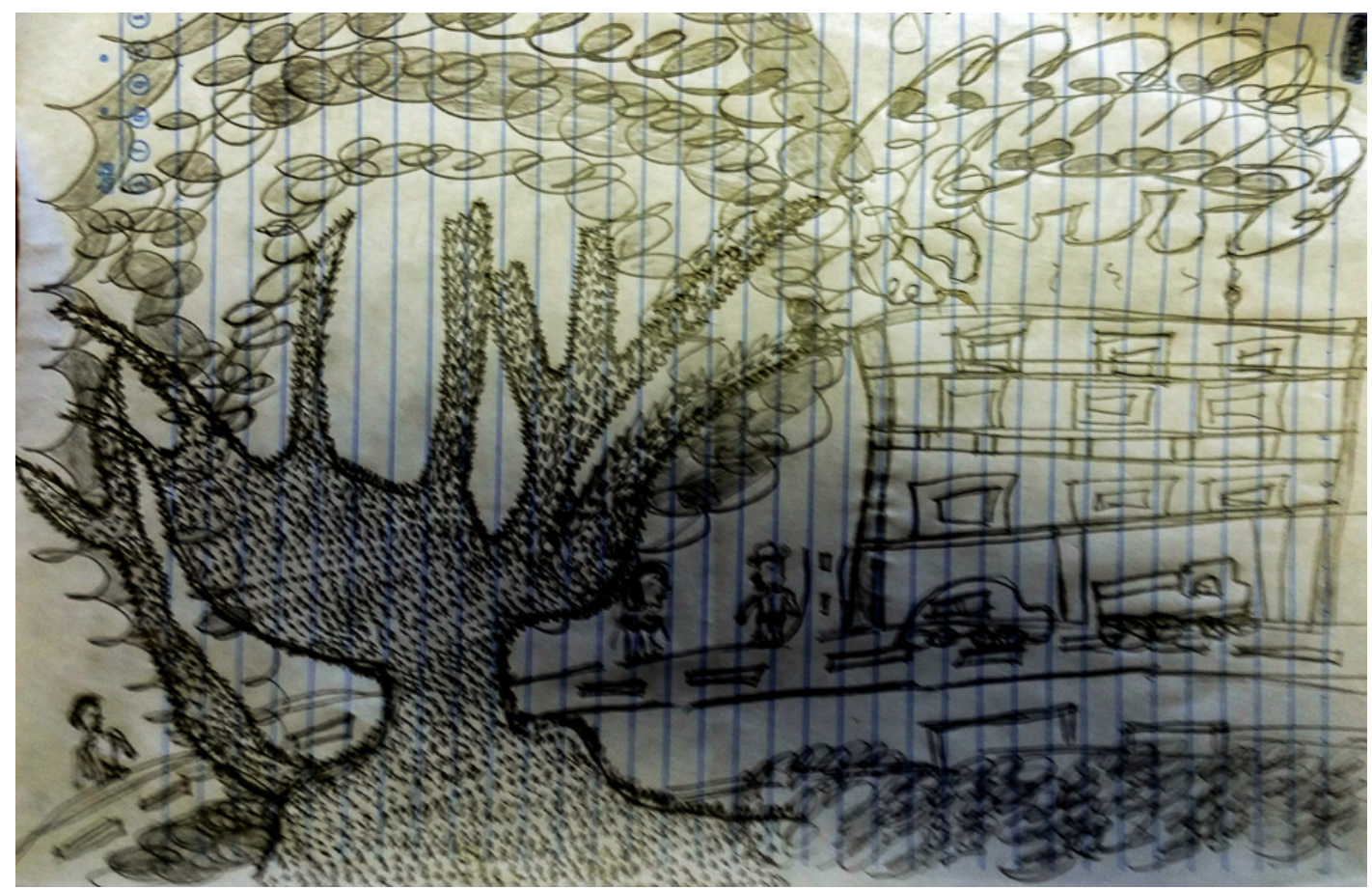

Imagem 3: Desenho de Jósimo Constant

Desenhar se revelou também como companhia em momentos de insegurança, solidão e tédio no campo. Os desenhos comunicaram mais do que a concretude dos prédios e ruas, as áreas verdes do local (ver Imagem 3). Foram utilizados diversos materiais, cores, texturas etc. para retratar as realidades observadas (ver Imagem 4). No conjunto, vimos vários pontos de vista sobre a quadra comercial: cima/frente, amplo/detalhe, fora/dentro etc. Mais do que espaços, muitos desenhos mostraram cenas, fluxos, animais e objetos, vãos e vazios e, muito interessantemente, as cores de pele das pessoas do local. O desenho revelava, assim, não ditos por parte da própria pesquisadora e os não vistos pelas demais colegas de turma.

Em sala de aula, compartilharam os desenhos. Depois, colocamos todos eles sobre a mesa maior e vimos juntas a produção da turma. Perguntas foram feitas, convergências foram nota- 
das, estratégias inovadoras de pictorização foram elogiadas, relações entre os textos e os desenhos foram elaboradas.

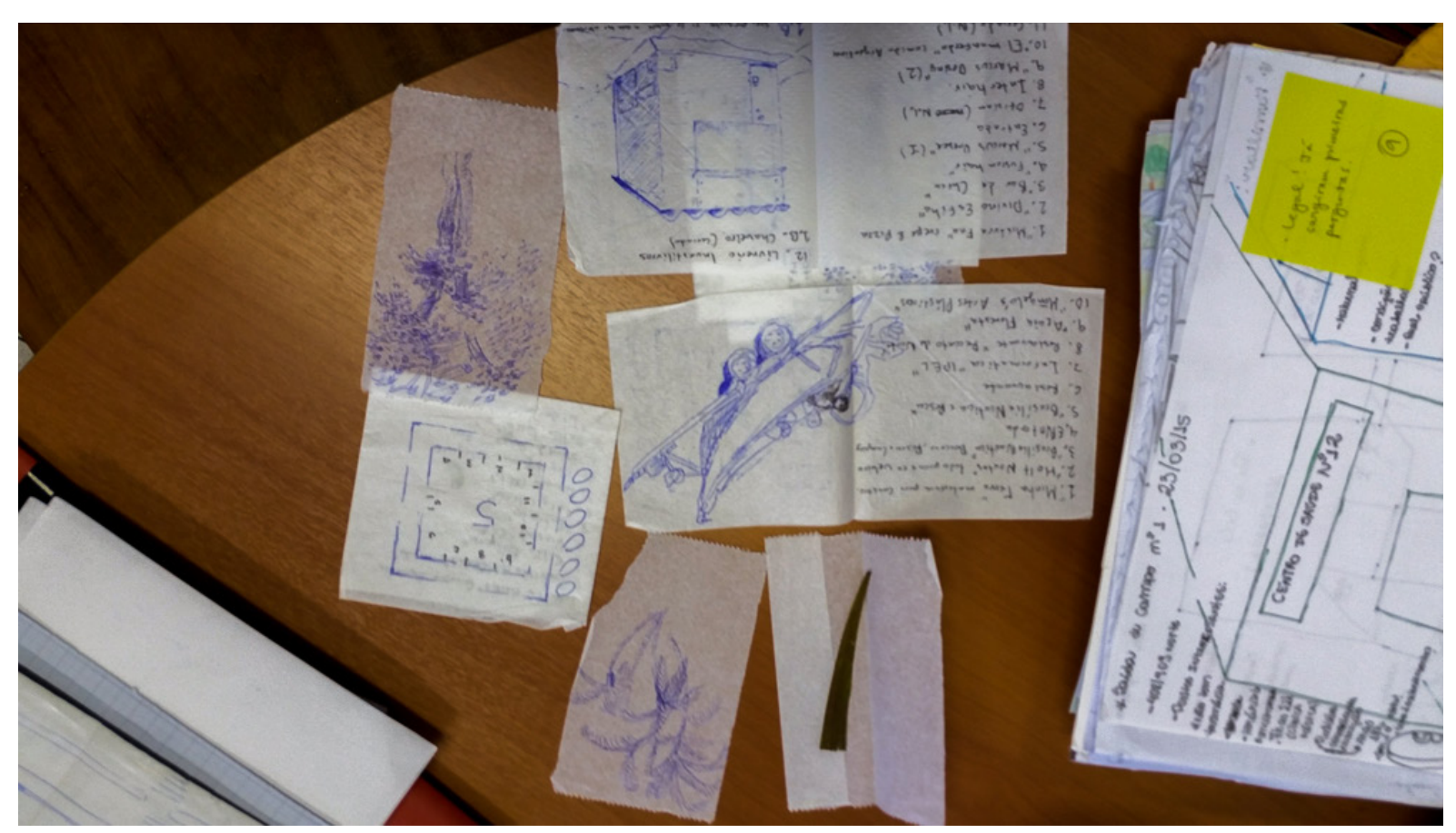

Imagem 4: Desenhos de Cesar Noyola Davalos

Como o próximo exercício, solicitamos a apresentação de um tema ("pergunta" ou "problema”) em um parágrafo. Esse tema lhes acompanharia ao longo do semestre, mas se manteria aberto, revisto e aprimorado sempre que provocado pelos dados que fossem surgindo. Cada novo exercício deveria se alimentar do anterior. A ideia era mostrar como os materiais de pesquisa vão se organizando em cadeia, não necessariamente progressiva e sim intercambiada e orgânica.

A partir daí, foi preciso conhecer quem já tinha pesquisado sobre aquele tema anteriormente. Visitaram portais como Scielo, Google Acadêmico, PubMed, BIREME, BVS, DOAJ, bases e repositórios (CAPES, IBICT, Ebrary) e a Plataforma Lattes. Discutimos como funcionam periódicos e indexadores acadêmicos e solicitamos que elaborassem uma primeira listagem bibliográfica sobre o tema escolhido. Utilizaram a Internet ou recorreram a bibliotecas. Lembramos que textos lidos em outras disciplinas também poderiam ter boas indicações bibliográficas, tentando valorizar o que já tivessem feito e acumulado até aquele momento na graduação. Aproveitamos para falar de COMUT, ABNT, Vancouver, EndNote, Mendley. Com a ajuda de Umberto Eco (1983[1977]), pensaram em como organizar essas referências. Viram que, já na etapa da pesquisa bibliográfica, era possível aprender sobre e, ao mesmo tempo, avançar o tema de pesquisa. 


\section{SAÍDA 2}

A segunda saída de campo previa que as estudantes travassem seu primeiro contato com pessoas. Conforme o tema, esse contato poderia ser em uma loja, um espaço de sociabilidade, com transeuntes ou moradoras de rua etc. $\mathrm{O}$ objetivo era suave: identificar e abordar alguém, apresentar a pesquisa e as pesquisadoras e convidar para uma conversa despretensiosa, sem roteiro, sem planos prévios. Era uma primeira aproximação para sentir o campo e o nível de abertura das pessoas. Aqui, a licença para ficar e o consentimento para conversar foram assuntos centrais. Foram notando que as pessoas consentiam sua presença por vezes clara e oralmente, outras vezes tácita e indiretamente. Entenderam que as negociações para lograrmos autorizações para ficar eram continuadas. Não eram necessariamente cumulativas e definitivas, mas deveriam acontecer diante de cada nova ação como abordar, perguntar, olhar, anotar, fotografar, gravar etc. Começaram a entender que o "não" poderia surgir de muitas formas e, embora frustrante, também comunicava algo a ser interpretado.

\footnotetext{
"higienizar" ou "mascarar" a nossa presença. No entanto, o trabalho de campo é tomado como, geralmente, sobre o "outro". E o que é "deixar falar" e "escutar" esse "outro"? Por onde navega a nossa suposta integridade intelectual e posicionamento político quando vamos para campo e falamos com as pessoas? Deveremos esquecer estes elementos temporariamente para estabelecer um diálogo com outros, para podermos realmente escutar sem julgar? Afinal de contas, não estou numa conversa entre amigos... E não procuro nem posso mudar as ideias de Val e entrar num debate. Mas também não me sinto confortável quando o meu gênero abre as portas a expressões machistas que eu normalmente questionaria diretamente. E quando a
}

\section{Imagem 5: Trecho do diário de campo de Carlota Moura}

Aos poucos, foram se questionando se deveriam concordar com tudo que lhes fosse dito em campo, como condição para serem aceitas e permanecer. Também aventaram como lidar com as controvérsias. Raquel Lustosa comentou sobre o seu "incômodo de incomodar". Muitas estudantes pensavam: "Eu já estou no espaço do outro. Já estou atrapalhando a vida dele. Eu tenho que ceder". Perguntamos à turma: Estamos mesmo atrapalhando? Quanto devemos ceder? Esses dilemas ficaram mais graves quando investidas sexuais foram relatadas por algumas pesquisadoras, quando quem atrapalhava eram os interlocutores (ver Imagem 5). A turma começava a navegar, na prática, pelas relações de poder que permeiam as relações de pesquisa. Era preciso cuidado com o outro, mas também cuidado consigo mesma. "É preciso se respeitar em campo", disse Raina Cassemiro.

Pairava certa tensão em abordar as pessoas e, por isso, optamos por entrar em campo paulatinamente, com poucas tarefas por vez. Tentávamos assoberbar menos as estudantes para que lidassem a seu próprio tempo com a timidez e a inexperiência. Também por isso o trabalho em dupla foi recomendado, para que esse primeiro trabalho de campo gerasse menos desamparo. Reconhecemos, contudo, que propor momentos fixados de antemão para realizar saídas de campo guarda bastante artificialidade. Essa foi apenas uma estratégia para trazer as saídas de campo para dentro da disciplina. Lembramos à turma como, em geral, a frequência e o horário das visitas são definidos em negociação com as interlocutoras em questão. Esse timing mais natural poderia, inclusive, contemplar o biorritmo da pesquisadora, sua agenda, nível de timidez e sensação de solidão. 
O exercício foi tomar notas durante a saída (se fosse possível e desejado) e depois escrever um diário de campo. ${ }^{5}$ Para muitas, seria o primeiro diário de campo produzido e havia certo desconhecimento sobre esse tipo de texto. Por isso, visitamos a biblioteca central da UnB e solicitamos que cada dupla encontrasse um diário de campo publicado, o folheasse e escolhesse trechos a serem lidos durante a aula. Ao final, discutimos: Que tipo de escrita é essa? Em que pessoa e tempo verbal acontece? É possível notar a presença da autora no texto? Como situações, cenas e personagens são descritos? Os diálogos aparecem em voz passiva, com travessão, aspas? Houve edição para que o texto fosse publicado?

Recomendamos que o diário fosse escrito tão logo o campo fosse deixado. De preferência na mesma noite ou, no mais tardar, na manhã seguinte. Lembramos que a memória é um ingrediente importante na recapitulação do que acontecera e que a tendência era que se diluísse com o passar do tempo. Monique Batista, uma das egressas do DAN convidadas para falar sobre sua monografia (Batista 2014), contou que aprendeu, ao escrever seus diários, que tudo deveria ser registrado, mesmo quando se achasse que não era um assunto relacionado ao seu tema de pesquisa.

Sugerimos que pensassem sobre a forma como o diário de campo seria escrito (no computador ou à mão, com caneta ou lápis, em caderno ou em folhas separadas) e onde conseguiriam se concentrar e se reconectar com a experiência vivenciada. Reforçamos que é preciso terminar a escrita de um diário para, só então, voltar ao campo. O ideal era não deixar os diários a serem escritos acumularem, pois arriscava-se esquecer detalhes vistos e ouvidos e confundir os diferentes dias de pesquisa. Caso desejassem, também poderiam registrar como se sentiam nas diversas situações, chamando a atenção para a importância das emoções na experiência etnográfica (Beatty 2005; Favret-Saada 2005; Grossi 2004).

A todo tempo, provocávamos cada aluna a inventar seu próprio jeito de escrever sobre a pesquisa. Cuidar dos registros era um pleito por valorizarem as informações trocadas com as interlocutoras e desafiarem uma aparente falta de peso que pode ser associada às conversas que acontecem em tom mais informal, rápido ou fragmentado. Escrever o diário de campo era uma forma de ritualizar a realização da pesquisa empírica, criando um momento específico para a memória ser acionada e a experiência revivida, agora de um ponto de vista um pouco distante e mais reflexivo e analítico. Além de registrar formalmente as saídas de campo, lembramos, inspiradas por Wright-Mills (1980[1959]), que o diário deve se manter sempre aberto, para inclusão de qualquer material relativo à pesquisa: sonhos, pensamentos marginais, cacos de informação ouvidos na rua (idem). Manter o diário alimentaria o hábito de autorreflexão, deixando nosso mundo interior sempre desperto, consolidando o hábito de escrever, deixando a mão sempre desembaraçada (ibidem). Seguimos a ideia de que ver, ouvir e escrever - a todo tempo, no campo ou alhures - guardam o caráter constitutivo da Antropologia (Cardoso de Oliveira 1998).

Sugerimos duas formas de escrita do diário: uma primeira para si, a mais "completa" possível, repleta de descrições concretas de cenário, figurino, contexto, discursos, fisionomias, tons de voz etc., produzida de modo livre, desinibido e catártico. E uma segunda forma revisada para ser compartilhada com a dupla e depois com as colegas e as professoras. Chamamos esse formato de "diário editado", já que o objetivo era circular as formas de escrita e descrição e não

5 Nós, professoras, também adotamos essa prática, registrando nossas impressões e relatos durante o semestre. Nossos "diários de aula" foram importantes para planejar atividades e condutas e, ao serem revisitados, para elaborar este artigo. 
constranger as estudantes em seus desabafos, inseguranças ou eventuais "equívocos" de forma ou de antropologia. Em sala de aula, trocaram diários, leram umas às outras e, ao se permitirem serem lidas, foram descobrindo juntas a miríade de percalços do fazer antropológico, percebendo que não estavam sozinhas nessas descobertas. Crescíamos juntas. O "erro" de uma era lição para todas. Isso humanizava o processo, tornava a antropologia mais próxima, mais possível, mais concreta. Os bastidores da "magia antropológica" (Silva 2000) iam sendo percorridos e, ao mesmo tempo, (des)construídos. A experiência da disciplina deixava de ser algo abstrato, que ninguém sabia como era produzido, para se tornar uma etnografia vivida (Peirano 2008).

Foram encontradas saídas interessantes e novos desafios. Notamos que o celular pode estar se tornando o novo caderno de campo, já que anotações (escritas ou gravadas) eram feitas no aparelho com facilidade e praticidade. Algumas gravavam um áudio tão logo deixassem o campo para não esquecer e, quando podiam, passavam para o registro escrito. Outras escreviam o diário com tudo o que lembrassem espontaneamente e, só depois, recorreram às anotações, provocando a memória. Maria Fernanda Borges contou sobre a saída de campo à mãe, ao namorado e à sua dupla, construindo o que chamou de "pré-diários". Ao narrar, lembrou de mais detalhes, afinou sua percepção e teve mais segurança para escrever o diário definitivo. Como nos exercícios anteriores, aqui também, como diziam, se sentiram "crisadas" (em crise) e tiveram que "fritar" (se desdobrar ou se esforçar) para encontrar soluções.

Entre escutar e escrever durante a saída de campo, por vezes voltaram para casa com parcas anotações, dificultando a redação do diário. Para driblar isso, Juliana Kitayama passou a rabiscar palavras-chave enquanto conversava com as pessoas. Outras disseram que foi difícil estabelecer a forma de narrar os diálogos que aconteciam em campo. Que tempo verbal ou voz empregar (passiva/ativa)? Como reconstruir as conversas descontraídas? Sugerimos também que registrassem suas próprias perguntas, para que diálogos e não monólogos (da interlocutora) fossem retratados e para que ficasse claro o contexto de enunciação, a resposta da interlocutora e o diálogo em curso. Notaram que tinham mais facilidade de escrever sobre encontros e pessoas com quem tinham mais empatia. Ponderaram sobre a própria presença no diário, se deveriam inserir sua reflexividade ou não, avançando na discussão sobre autoria, subjetividade e autoridade em campo e no texto. Ao ler o diário da dupla, perceberam complementariedades, mas também focos e interpretações diferentes.

\section{SAÍDAS 3 E 4}

Nas terceira e quarta saídas de campo propusemos que conversassem novamente com a mesma interlocutora, agora de modo mais aprofundado, com perguntas mais estruturadas. Seria preciso estar preparada para não encontrar a mesma pessoa naquela saída e/ou receber uma negativa em engajar-se de novo na pesquisa. Como iam percebendo a cada saída, "jogos de cintura" eram importantes para contornar as "saias justas" (Bonetti e Fleischer 2007). A dupla preparou e submeteu ao escrutínio da turma um roteiro de perguntas e suas estratégias para fazer a nova abordagem. Novamente, comentários foram feitos e o set de perguntas ganhou em coerência, prioridade e flexibilidade. Atentaram para perguntas redundantes e fechadas ( $\operatorname{sim} /$ não), para os riscos da indução de conteúdo, dos pressupostos etnocêntricos e do valor de exemplos e histórias para ilustrar pontos de vista muito abstratos ou filosóficos. 
Para essas saídas, fizemos oficinas de fotografia e vídeo, investindo em formas menos discursivas de construção e apresentação de dados etnográficos. Lemos textos da antropologia visual, analisamos imagens, fizemos exercícios práticos. Algumas estudantes utilizaram seus aparelhos de telefone celular, outras recorreram a câmeras simples ou mesmo semiprofissionais. As duplas se filmaram e depois revisaram os resultados, pensando em enquadramento, som, abordagem etc. Os exercícios de vídeo foram bem simples: visavam apenas ensinar a como gravar entrevistas e realizar imagens dos ambientes. Não pretendíamos realizar filmes, mas incitar as estudantes a atentar para informações visuais e sonoras (barulhos e silêncios) durante as gravações, bem como para as repercussões dos equipamentos sobre a interação.

Mas os exercícios de foto foram mais complexos. Após uma oficina de análise de imagens (onde discutimos enquadramento, composição, foco, ângulo, planos, cores, etc.), propusemos um exercício de construção de narrativa visual. As estudantes deveriam, no pavilhão de aulas e depois na quadra comercial, tirar fotografias para elaborar um ensaio fotográfico. Sugerimos que utilizassem do sequenciamento das imagens e da combinação entre fotos e legendas para contar uma história. Imagens e textos deveriam ter importância equivalente, ser independentes e dialogar de forma colaborativa (Mitchell 2002). Henrique Rocha, por exemplo, realizou o ensaio reproduzido nas imagens 6 a 8 .

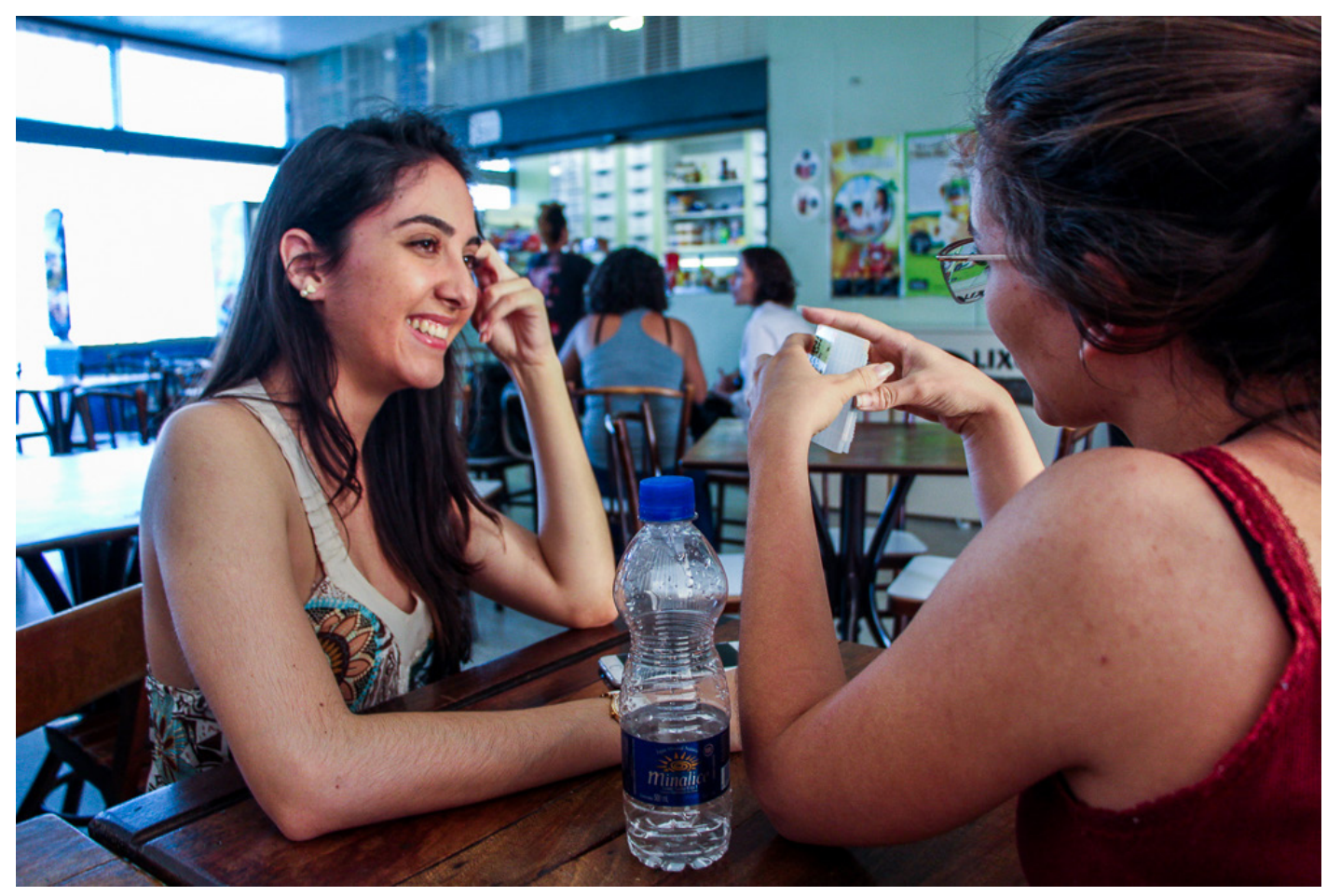

Imagem 6: Após a aula as jovens decidem passar pela cafeteria do Pavilhão João Calmon para vender alguns ingressos para a festa junina da medicina.

As estudantes também deveriam definir as atribuições das duplas/trios para as terceira e quarta saídas de campo: quem se ocuparia do caderno, da câmera, do roteiro de perguntas, etc. Sugerimos que os papéis estabelecidos na terceira saída se invertessem na quarta, possibilitando que as estudantes experimentassem com quais equipamentos se sentiam mais confortáveis. Pouco a pouco, compreendiam a importância de treinamento, preparação e organização prévios. 


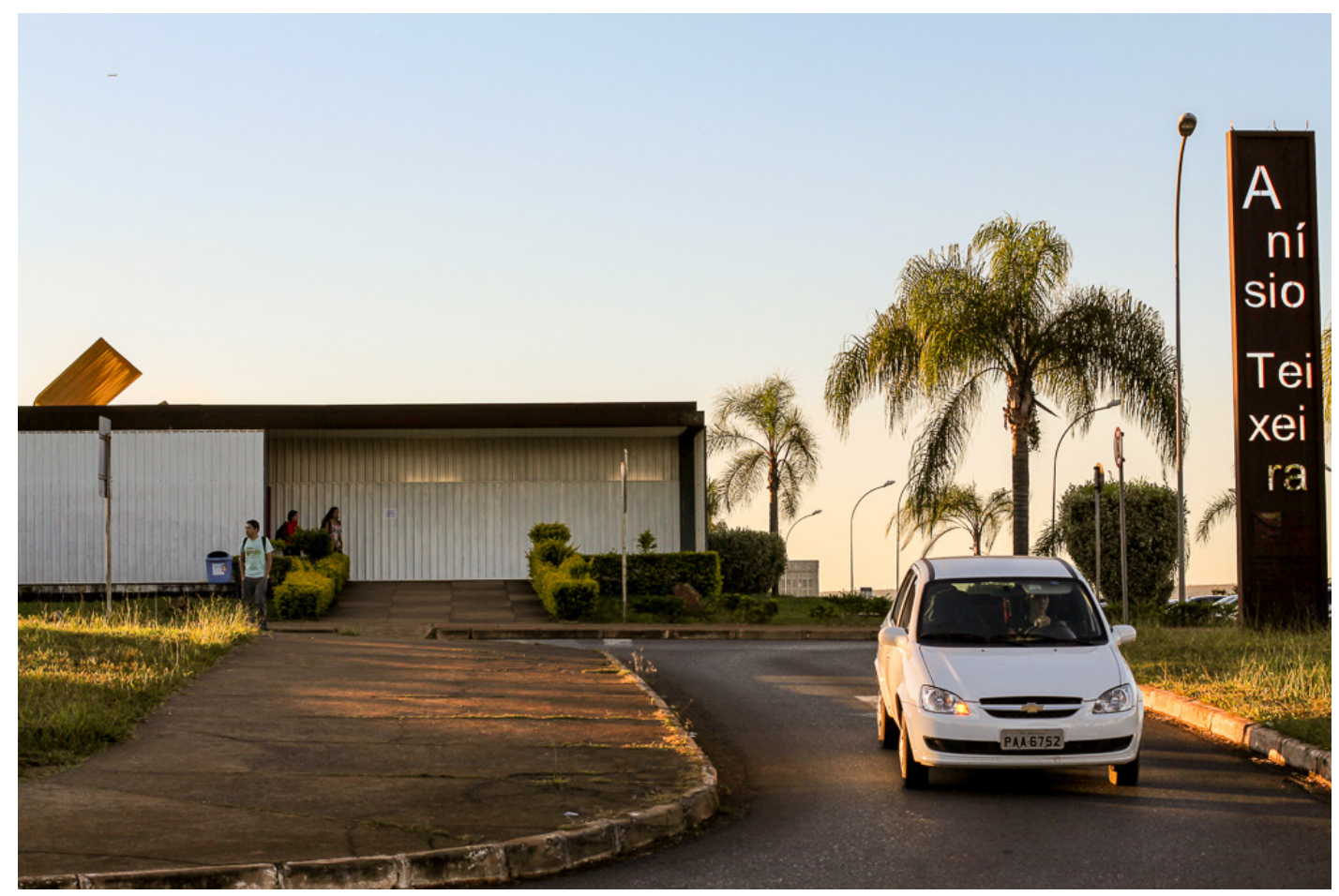

Imagem 7: Após a aula das 16h muitos já encerram suas aulas na UnB e vão-se embora. O sol já se encontra inclinado, próximo ao momento de se por.

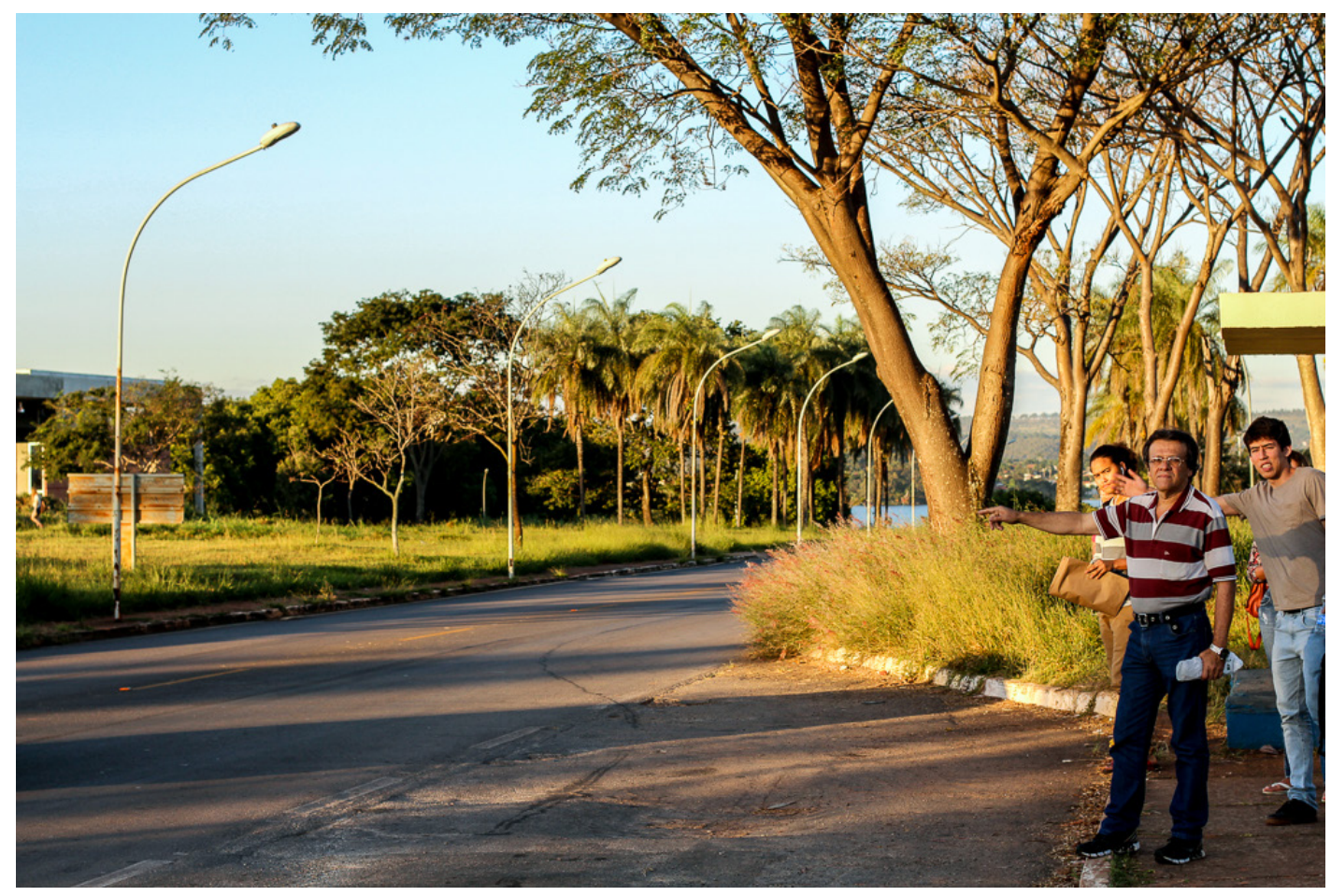

Imagem 8: O ambiente universitário é muito heterogêneo: trabalhadores, estudantes, etc. Na hora de ir embora, muitos utilizam o transporte público para saírem da universidade.

Acompanhadas de câmeras e gravadores, experimentaram resultados como som deficitário, luz estourada, travelling tremido, enquadramentos que alienavam os sujeitos. Se incomodaram com a agência dos equipamentos que, muitas vezes, conseguiam consentimentos mais facilmen- 
te do que as estudantes haviam logrado nas primeiras saídas, quando estavam "desequipadas". Ou com a falta de espontaneidade frente às câmeras. Aventaram o que poderia ser feito quando não havia a autorização formal para fotografar as pessoas e começaram a pensar em planos abertos, cenas externas, ângulos das costas ou sombras das pessoas. Frustraram-se com a bateria que acabou, o aparelho que não funcionou ou a incapacidade de acionar suas funções de modo estratégico. Notaram, por outro lado, que poderiam filmar detalhes impossíveis de serem captados com a fala ou a escrita.

As entrevistas gravadas em áudio, produzidas na terceira saída, foram transcritas. As entrevistas gravadas em vídeo, produzidas na quarta saída, foram decupadas. Essas tarefas foram divididas pela dupla, o resultado foi trazido, circulado e discutido coletivamente em sala de aula.

\section{SAÍDA 5}

Após as saídas de campo para realização de caminhadas, conversas, entrevistas, fotos e vídeos, entramos em uma etapa que visava discutir formas de despedida, devolução e restituição. Chegávamos ao final da disciplina. Lemos alguns textos e analisamos diferentes estratégias de devolução (Rial 2014; Gama 2009; Fleischer 2015). Consideramos importante nos despedir formalmente, explicando às interlocutoras o que fazíamos, para onde iriam os materiais produzidos, quais seriam as próximas etapas daquela minipesquisa, da disciplina de MTAS, do curso de graduação etc. Assim, na quinta e última saída de campo, algumas estudantes entregaram às suas interlocutoras fotos, entrevista transcrita, vídeo, poesia, marcador de livros. Algumas se voluntariaram para ajudá-los em seus trabalhos. Um estudante resolveu fazer suas refeições na lanchonete que vinha frequentando. Cada dupla encontrou sua maneira de retribuir a atenção recebida e valorizar a relação estabelecida.

Além disso, era hora de elaborar o "trabalho final". Acordamos que deveria ser uma autorreflexão do próprio aprendizado e desempenho ao longo do semestre. Propusemos que as estudantes refletissem individualmente sobre o que haviam vivido. Que avaliassem o que haviam aprendido com as leituras, seminários, oficinas, saídas de campo, exercícios, com a companhia da dupla, da turma, das interlocutoras e das professoras, com a produção individual e coletiva, dentro e fora da sala de aula, com escrita ou com outros meios de expressão e registro. Deveriam considerar essa gama de experiências para construírem uma comunicação de sete minutos a ser apresentada diante da turma. Assim, o objetivo não foi analisar os dados construídos (como é comum ao final das disciplinas temáticas) ou elaborar um projeto de pesquisa, mas realizar uma autoanálise retrospectiva do trabalho empreendido ao longo de MTAS. Que técnicas funcionaram melhor para a estudante? Quais foram as maiores dificuldades enfrentadas? Quais as descobertas mais importantes? O que imaginam poder ser útil quando empreendessem sua pesquisa monográfica?

Cada apresentação foi uma surpresa: utilizaram diferentes mídias, aproveitaram de modo criativo os exercícios elaborados, criaram poesia e colagens, usaram autoironia e autocrítica para promover deslocamentos e rever hierarquias e certezas. Foi um momento importante para que sistematizassem o vivido e percebessem os aprendizados comuns, gerados individual e coletivamente. Também serviu para percebermos como é possível produzir Antropologia com humor, arte e diferentes formas expressivas. Ficou clara a aposta no aprendizado horizontal, em que o 
"conteúdo" de uma disciplina e a "antropologia" de modo geral puderam ser produzidos com qualidade já por graduandas e dentro, perto e nas redondezas da sala de aula.

\section{Considerações finais}

A possibilidade de vivenciar e partilhar uma primeira experiência etnográfica de maneira coletiva foi ressaltada como produtiva por todas as estudantes, mas em especial pelas mais tímidas. Se movê-las de uma posição de conforto gerava constrangimentos no início e algumas faziam caretas quando convidadas a participar, ao interagirem com uma desconhecida ou mesmo sentarem em círculo, ao final notamos uma mudança em suas interações e comportamentos. Marina Fonseca avaliou positivamente que essa primeira experiência de pesquisa empírica tivesse acontecido em dupla e com o suporte constante da turma como um todo. Explicou que, até então, as leituras feitas no curso sugeriam pensar a Antropologia como prática realizada sempre individualmente. Chamou de "Síndrome de Indiana Jones", aquele que tudo faz e tudo resolve sozinho. Dali em diante, ela via a possibilidade de atuar em equipes de pesquisa, de construir redes de leitoras para seus textos, de poder compartilhar as angústias do campo. Além disso, como Juliana Kitayama lembrou, trabalhar em dupla permitiu que ela se percebesse como pesquisadora por contraste e também por espelhamento com sua parceira.

Os exercícios individuais e coletivos estimulavam diferentes formas de se expor e negociar ações. Assim, propor que MTAS fosse um curso coletivo foi também uma tentativa de ajudar a preparar as estudantes para os próximos passos da sua atuação profissional, quando a polifonia e a policromia possivelmente estarão presentes em suas trajetórias. Ao estimularmos o senso crítico das alunas, mas também a reflexão sobre a melhor forma de apresentar tais críticas, investíamos em uma antropologia mais empática e menos solitária. Este ponto é raríssimas vezes trabalhado em sala de aula.

Ao longo do curso as estudantes escreveram, pensaram e leram muito. Passaram a ler o que as colegas escreviam e a ouvir o que relatavam. Muitas comentaram que nunca haviam escrito tanto em uma disciplina, mas que não havia sido pesado. Ao contrário, começavam a perceber como escrever e reescrever aquecia, soltava e aprumava a mão (Fleischer e Damásio 2015). Tomar notas, prestar atenção e até dirigir perguntas enquanto outra pessoa conta algo é uma tarefa muito comum nas atividades acadêmicas e foi um dos maiores desafios reportados pelas estudantes ao longo da disciplina. Como Peirano recomenda (2008), ler na íntegra monografias e debater com as autoras reviu a prática de só lermos os cânones mortos, famosos e distantes ${ }^{6}$. Também se mostrou como uma estratégia para tornar a prática da disciplina mais palpável e acessível às iniciantes: elas viam que pessoas como elas realizavam, defendiam e ganhavam prêmios com seus trabalhos. ${ }^{7}$ Muitas nunca tinham lido uma monografia completa. Achavam algo quase impossível de ser feito ou vislumbrado. Todos esses textos, produzidos artesanal e localmente, ajudaram Raina Cassemiro a dizer, ao final do curso, "Antes era tudo abstrato. Agora, já está mais concreto, já consigo imaginar como acontece uma pesquisa”. Mais do que isso, estávamos todas, como disse Carlota Moura, a "desierarquizar o conhecimento".

6 Para uma discussão provocativa sobre a construção dos cânones conceituais nos cursos de Antropologia no país, ver Sanabria (2005).

7 Inclusive, o DAN criou o prêmio anual "Martin Novion de Melhor Dissertação de Graduação". Para acesso ao último edital do prêmio, ver http://dan.unb.br 
Ana Clara Damásio comentou que "Muitas colegas tiveram problemas durante a pesquisa”. Mas perceberam que as demais também eram inexperientes, erravam, tentavam de novo e nem sempre chegavam onde desejavam. Perceberam que apesar disso tudo, não ficariam estigmatizadas como "menos brilhantes" nem teriam a "carreira" comprometida. A sala de aula (e suas adjacências) ia se transformando num laboratório humanizado, onde todas estariam na berlinda vez por outra e todas as outras estariam a postos quando tombos ou angústias acontecessem. Iam percebendo que não saber e não conseguir eram parte fundante e constante da Antropologia. Se bem revertidos em curiosidade, criatividade e empenho poderiam funcionar como máquina propulsora da boa etnografia e da boa teoria.

Se não há métodos pré-definidos na Antropologia, se eles costumam ser desenhados conforme o tema, o campo e as pessoas que conhecemos, é importante construirmos um repertório de experiências. As histórias do campo de uma colega serviram também para aperfeiçoar o campo das demais, para adensar nosso estofo ético e metodológico, para refletir sobre os andaimes da pesquisa que tendem a sumir dos artigos, da memória e dos espaços oficiais (Silva 2000). Cada vez que confidenciavam uma "anedota do campo", contribuíam para a Antropologia avançar, sobretudo para se recriar. Ao final de MTAS, Matheus Caetano comentou: "Agora podemos contar as nossas próprias anedotas”. Notavam que haviam passado por um ritual de iniciação importante e, um pouco mais familiares com a experiência de campo, sentiam-se partícipes da comunidade antropológica. Assim, percebiam que "trabalho de campo é vivência", como ressaltou Jósimo Constant, em diálogo com o que Brandão (2007) ensinou: precisa ser vivido com frequência e continuidade, a partir de sua subjetividade, biografia e estilo.

A disciplina contou com muita dinamicidade, desde a mudança da disposição dos moveis dentro da sala, o local de realização das aulas, à variedade de materiais disponíveis para leitura e discussão, à diversidade de autoras a serem conhecidas. Esse quadro contribuiu, notamos, para que cada aula apresentasse surpresas e fosse construída por todas as pessoas presentes e não apenas pelas professoras. Embora tivéssemos objetivos a cumprir em cada aula, não sabíamos ao certo por onde ela caminharia. Muitas vezes, terminávamos a aula já pensando em mais materiais para subsidiar as discussões seguintes. A falta de controle das professoras foi positivamente absorvida pela turma que, mais e mais, passou a entender que também era responsável por fazer a aula acontecer. Ficava difícil, portanto, as estudantes se dispersarem com seus celulares e computadores. Precisavam estar atentas a cada nova rota que a aula tomava, muitas vezes implicando a participação de sua experiência, opinião ou exercício produzido.

A forma como propusemos MTAS buscou ser leve, divertida e, sobretudo criativa. Foi um convite a pesquisar, a olhar o mundo com curiosidade, a aprender em grupo, a experimentar. Convidamo-nas a colocar a mão na massa, experimentar formas de escrita, produzir desenhos, fotografias, vídeos, se relacionarem com pessoas e técnicas desconhecidas etc. Em suma, incitamos a produção de um conhecimento de modo afetivo (MacDougall 1994). Acreditamos que a sala de aula é um laboratório de criação (de métodos, estratégias de pesquisa, conhecimentos, encontros e relações), de socialização do ethos da Antropologia, de imbricamento entre pesquisa, extensão e ensino. Um local propício para pensar sobre e fazer acontecer a "cozinha da pesquisa antropológica", como bem definiu a estudante Sarah Almeida. 


\section{REFERÊNCIAS BIBLIOGRÁFICAS}

Batista, Jéssica Monique. 2014. Cabeça ruim, morrência do braço e perna esquecida: Convivendo ecuidando do derrame na Guariroba, Ceilândia/DF. Dissertação [Graduação em Antropologia]. Orientadora: Soraya Fleischer. Brasília: UnB.

Beatty, Andrew. 2005. "Emotions in the field: What are we talking about?" The Journal of the Royal Anthropological Institute, Vol. 11, No. 1 (Mar.): 17-37.

Bonetti, Alinne, Soraya Fleischer (Orgs). 2007. Entre saias justas e jogos de cintura. 2. ed. Santa Cruz do Sul: EdUNISC.

Brandão, Carlos Rodrigues. 2007. "Reflexões sobre como fazer trabalho de campo". Sociedade e Cultura, 10(1): 11-27.

Cardoso de Oliveira, Roberto. 1998. "O trabalho do antropólogo: olhar, ouvir, escrever" Pp.1735 in O trabalho do antropólogo. Brasília/ São Paulo: Paralelo 15/Editora UNESP.

Eco, Umberto. 1983 [1977]. “A pesquisa do material”. Pp.35-81 in Como se faz uma tese. São Paulo: Perspectiva.

Favret-Saad, Jeanne. 2005. "Ser afetado". Cadernos de Campo, 13: 155-161.

Fleischer, Soraya. 2015. "Autoria, subjetividade e poder: Devolução de dados em um centro de saúde na Guariroba (Ceilândia/DF)”. Ciência e Saúde Coletiva, 20(9): 2649-2658.

.2012. "Atenção básica de saúde, cronicidade e Ceilândia: O que tudo isso tem a ver com o ensino da Antropologia?”. Percursos 13: 23-39.

Fleischer, Soraya e Ana Clara Damasio. 2015. “Quais são os desafios de escrever durante o curso de graduação em antropologia?”. Entrevista com Soraya Fleischer por Ana Clara Damásio. Textos Graduados: 1-14.

Fleischer, Soraya, Rosana Castro, Laísa Cardoso, Amanda Duarte Machado, Gíllian Arêa Leão Silva, Nathan Lima Virgílio, e Géssica de Oliveira Motta. 2014. "Ensaio à la Nacirema: Relato de uma experiência docente em Antropologia”. Café com Sociologia, 3(1): 18-40.

Gama, Fabiene. 2009. "Etnografias, auto-representações, discursos e imagens: somando representações”. Pp: 91-114 in Devires imagéticos: Representações/Apresentações de si e do outro, organizado por Marco Antônio Gonçalves e Scott Head. Rio de Janeiro: 7letras.

Gama, Pedro Ferraz e Karina Kuschnir. 2014. "Contribuições do desenho para a pesquisa antropológica”. Revista do CFCH: 1-5.

Geertz, Clifford. 1995. After the fact: two countries, four decades, one anthropologist. Boston: Harvard University Press.

Gomes, Mércio Pereira. 2015. Antropologia. São Paulo: Contexto.

Grossi, Miriam. 2014. "A dor da tese". Ilha, 6(1-2): 221-232.

Grossi, Miriam, Antonella Tassinari, e Carmen Rial. 2006. Ensino de Antropologia no Brasil: Formação, práticas disciplinares e além-fronteiras. Blumenau: Nova Letra.

Günther, Luísa. 2013. Experiências (des)compartilhadas: arte contemporânea e seus registros. Tese (Doutorado em Sociologia). Brasília: Universidade de Brasília.

MacDougall, David. 1994. "Mas, afinal, existe realmente uma antropologia visual?”. Pp. 71-75 in Catálogo da Mostra Internacional do Filme Etnográfico. Rio de Janeiro.

Malinowski, Bronislaw. 1984 [1922]. Argonautas do Pacifico Ocidental. São Paulo: Editora Abril. Mauss, Marcel. 1993[1947]. Manual de etnografia, tradução de J. Freitas e Silva. Lisboa: Dom Quixote.

Mitchell, William John Thomas. 2002. "O ensaio fotográfico: quatro estudos de caso". Cadernos de Antropologia e Imagem, 15(2): 101-131.

Peirano, Mariza. 2008. “Etnografia ou a teoria vivida”. Revista Ponto Urbe, 2(2): 1-10. 
Rial, Carmen Silvia de Moraes. 2014. "Roubar a alma: ou as dificuldades da restituição". Tessituras, 2(2): 201-212.

Sanabria, Guillermo Vega. 1995. O ensino da antropologia no Brasil: um estudo das formas institucionalizadas de transmissão da cultura. Dissertação [Mestrado em Antropologia social]. Florianópolis: Universidade Federal de Santa Catarina.

Schweig, Graziele Ramos. 2015. Aprendizagem e ciência no ensino de Sociologia na escola: um olhar desde a Antropologia. Tese (Doutorado em Antropologia Social). Porto Alegre: Universidade Federal do Rio Grande do Sul.

Silva, Vagner Gonçalves da. 2000. O antropólogo e sua magia: trabalho de campo e texto etnográfico nas pesquisas antropológicas sobre as religiões afro-brasileiras. São Paulo, Edusp.

Taussig, Michael. 2011. I swear I saw this: drawings in fieldwork notebooks, namely my own. Chicago: University of Chicago Press.

Tavares, Fátima, Simoni Lahud Guedes, e Carlos Cardoso. 2010. Experiências de ensino e prática em Antropologia no Brasil. Brasília, Ícone Gráfica e Editora.

Velho, Gilberto. 1981. "Observando o Familiar". Pp. 121-133 in Individualismo e cultura. Rio de Janeiro: Zahar.

Wright-Mills, Charles. 1980[1959]. "Do artesanato intelectual". Pp: 211-243 in A imaginação sociológica. Rio de Janeiro: Zahar.

\section{In the RESEARCH KITCHEN: EXPERIENCES WITH TEACHING "Methods AND Techniques of Social Anthropology"}

This article presents the author's experience of conducting an undergraduate course on research methods and techniques in anthropology. The course, common to a number of degree course schemes in social sciences, was carried out in a practice-oriented, based on reading and writing activities, hands-on workshops in drawing, photography and filmmaking, and by means of five collective field excursions which results were later discussed in the classroom. The usual stages of fieldwork, as well as the different techniques to accomplish these stages, were equally discussed. This all happened in a decidedly concrete manner, as to encourage the students to experiment reality in a critical and reflexive way. In this sense, the article seeks to contribute to the theory and practice of teaching anthropology.

Keywords: anthropology, research methods, creativity, horizontal learning

Recebido em: 2016-07-07

Aceitado em: 2016-09-13 